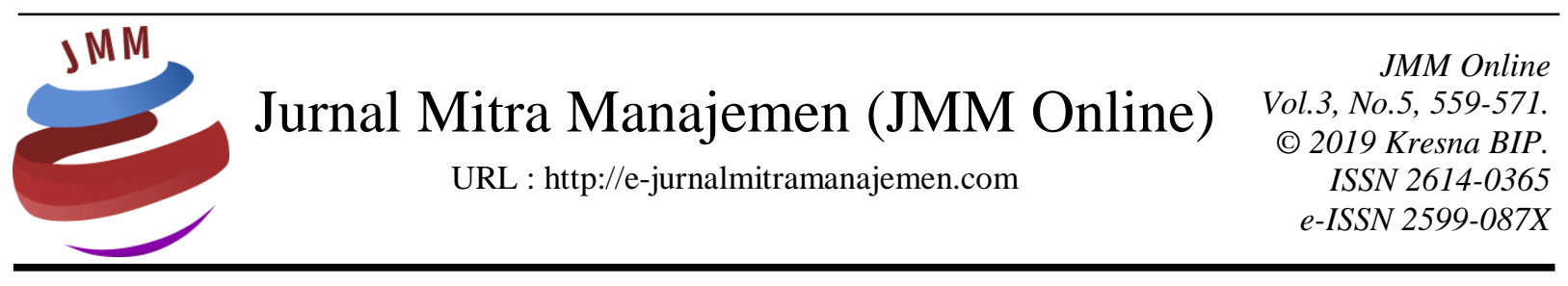

\title{
ANALISIS PENGARUH MOTIVASI, DISIPLIN KERJA DAN BUDAYA ORGANISASI TERHADAP KINERJA PEGAWAI BAKORWIL BOJONEGORO
}

\author{
Vivit Nurhidayah $^{1)}$, Woro Utari ${ }^{2)}$, C. Sri Hartati ${ }^{3)}$ \\ Badan Koordinasi Wilayah Bojonegoro
}

INFORMASI ARTIKEL

Dikirim : 10 Mei 2019

Revisi pertama : $16 \mathrm{Mei} 2019$

Diterima : 21 Meil 2019

Tersedia online : 31 Mei 2019

Kata Kunci : Motivasi Kerja, Disiplin Kerja, Budaya Organisasi

Email : vivit_atmo@yahoo.com
ABSTRAK

Tujuan dari dilaksanakannya penelitian adalah untuk mendeskripsikan motivasi, disiplin kerja, budaya organisasi dan kinerja pegawai di Bakorwil Bojonegoro. Untuk menguji dan menganalisis pengaruh motivasi, disiplin kerja, budaya organisasi secara simultan dan pasrsial terhadap kinerja pegawai di Bakorwil Bojonegoro.

Jenis penelitian ini adalah penelitian explanatory yaitu penelitian yang bertujuan untuk menguji hipotesis dengan menggunakan pendekatan penelitian kuantitatif. Populasi dalam penelitian ini adalah pegawai Bakorwil Bojonegoro yang berjumlah 62 orang. Teknik pengambilan sampel yang digunakan dalam penelitian ini diambil secara total atau menggunakan metode sensus sampling. Metode analisis yang digunakan dalam penelitian adalah berbentuk regresi linier berganda (multiple regression linier) dengan bantuan software SPSS.

Hasil penelitian menunjukkan bahwa kondisi variabel motivasi kerja, Disiplin kerja, Budaya organisasi dan kinerja pegawai pada Bakorwil di Bojonegoro semuanya dalam kategori baik. Motivasi kerja, Disiplin kerja dan Budaya organisasi secara simultan mempunyai pengaruh yang signifikan terhadap kinerja pegawai Bakorwil di Bojonegoro. Variabel motivasi kerja, Disiplin kerja dan Budaya organisasi pada penelitian ini memberikan kontribusi sebesar $36.3 \%$ terhadap kinerja pegawai Bakorwil di Bojonegoro. 


\section{PENDAHULUAN \\ Latar Belakang}

Aturan penyelenggaraan pemerintah daerah telah berubah. seiring dengan berubahnya peraturan, mempunyai dampak langsung terhadap kemandirian pemerintahan daerah yang bersangkutan. tuntutan akan kebutuhan yang semakin tinggi sebagai dampak krisis ekonomi yang berakibat pada perubahan kebutuhan hidup pegawai. penemuan terbaru menyatakan perubahan peraturan menyebabkan beban kebutuhan pegawai semakin tidak terpuaskan. Perubahan peraturan juga berakibat pada menurunnya motivasi dan disiplin kerja pegawai dalam menjalankan kinerjanya dalam instansi tersebut.

Tercapainya tujuan yang ada di dalam perusahaan atau instansi tidak hanya tergantung pada peralatan yang serba canggih, modern serta sarana dan prasarana yang begitu lengkap, tetapi justru tergantung pada sumber daya manusia yang melakukan pekerjaan itu sendiri. Perkembangan suatu instansi sangat ditentukan dari keberhasilannya mengelola sumber daya manusia yang ada dalam perusahaan tersebut. Pengelolaan sumber daya manusia yang dimaksudkan adalah bahwa perusahaan harus mampu untuk menyatukan persepsi pegawai dan pimpinan perusahaan dalam rangka mencapai tujuan instansi tersebut. Tujuan instansi dapat dibentuk melalui pembentukan kinerja dan sikap mental bekerja yang baik dengan dedikasi dan loyalitas yang tinggi terhadap pekerjaannya, memberikan motivasi kerja, bimbingan, pengarahan dan koordinasi yang baik dalam bekerja.

Banyak permasalahan yang dihadapi oleh bangsa Indonesia mengenai sumber daya manusia ini dikarenakan penanganan terhadap kualitas sumber daya manusia yang relatif rendah bahkan diabaikan. Jumlah sumber daya manusia yang besar apabila digunakan secara efektif dan efisien akan bermanfaat untuk menunjang gerak lajunya pembangunan nasional yang berkelanjutan. Melimpahnya sumber daya manusia yang ada saat ini mengharuskan berfikir secara seksama yaitu bagaimana dapat memanfaatkan sumber daya manusia secara optimal.

Selain motivasi yang dapat berpengaruh terhadap kinerja pegawai adalah disiplin kerja. Disiplin kerja merupakan upaya pengaturan waktu dalam bekerja yang dilakukan secara teratur dengan mengembangkan dan mengikuti aturan kerja yang ada (Wardana 2008:601). Disiplin kerja yang sering menjadi kendala dalam suatu instansi yaitu pegawai seringkali datang lewat dari waktu yang ditetapkan, pulang kerja sebelum waktu yang ditetapkan oleh instansi terkait dan pegawai tidak dapat menyelesaikan pekerjaan tepat pada waktunya.

Disiplin menjadi modal yang diperlukan untuk mencapai tujuan yang diinginkan. Sehingga keberadaan disiplin kerja sangat diperlukan dalam suatu instansi perusahaan, karena dalam suasana disiplin sebuah organisasi atau instansi akan dapat melaksanakan program-program kerja sehingga dapat mencapai sasaran yang telah ditetapkan. Disiplin kerja merupakan cerminan sikap seseorang dalam menghargai waktu, kesadaran, dan kepatuhan terhadap peraturan yang berlaku, baik yang tertulis maupun tidak tertulis serta sanggup menjalankannya, dan tidak mengelak sanksisanksinya apabila ia melanggar tugas dan wewenang yang diberikan kepadanya.

Untuk meningkatkan kinerja pegawai di suatu instansi perlu adanya budaya organisasi karena budaya organisasi merupakan pokok penyelesaian masalah-masalah 
eksternal dan internal yang pelaksanaannya dilakukan secara konsisten oleh suatu kelompok yang kemudian mewariskan kepada pegawai atau anggota sebagai cara yang tepat untuk memahami, memikirkan, dan merasakan terhadap masalah. (Peter F. Druicker dalam Utami, 2017:3).

Phithi Sithi Amnuai dalam Prabundu (2014:5) mendefinisikan budaya organisasi adalah seperangkat asumsi dasar dan keyakinan yang dianut oleh anggotaanggota organisasi, kemudian dikembangkan dan diwariskan guna mengatasi masalahmasalah adaptasi eksternal dan masalah integrasi internal. Hubungan budaya organisasi dengan kinerja pegawai sangat di perlukan di perusahaan karena budaya organisasi mengacu ke suatu sistem makna bersama yang dianut oleh anggota-anggota yang membedakan organisasi itu dari organisasi-organisasi lain. Sistem makna bersama ini, bila diamati dengan lebih saksama, merupakan seperangkat karakteristik utama yang dihargai oleh organisasi itu.

Hasil kerja yang kurang maksimal tentu akan memberi dampak terhadap kinerja pegawai tersebut. Kinerja merupakan kesediaan seseorang atau kelompok orang untuk melakukan sesuatu kegiatan dan menyempurnakannya sesuai dengan tanggung jawabnya dengan hasil seperti yang diharapkan. Jika dikaitkan dengan kinerja sebagai kata benda dimana salah satu entrinya adalah hasil dari suatu pekerjaan pengertian kinerja adalah hasil kerja yang dapat dicapai oleh seseorang atau kelompok orang oleh suatu perusahaan sesuai dengan wewenang dan tanggung jawab masing-masing dalam upaya pencapaian tujuan perusahaan secara legal, tidak melanggar hukum dan tidak bertentangan dengan moral atau etika (Rivai dalam Utami, 2017:4).

Berdasarkan pengamatan terhadap kinerja pegawai yang telah dilakukan terhadap pegawai di Bakorwil Bojonegoro adalah kurang memiliki strategi-strategi untuk meningkatkan produktivitasnya dan pemimpin juga kurang mempertimbangkan faktor sumber daya manusia yang bekerja di Bakorwil tersebut. Pegawai kurang memiliki kreativitas dan keberagaman model dalam bekerja sehingga menghasilkan kinerja yang terkesan stagnan.

\section{Rumusan Masalah}

Berdasarkan uraian pada latar belakang tersebut di atas, maka peneliti merumuskan masalah sebagai berikut:

1. Bagaimana deskripsi motivasi, disiplin kerja, budaya organisasi dan kinerja pegawai di Bakorwil Bojonegoro?

2. Apakah motivasi, disiplin kerja, budaya organisasi secara simultan berpengaruh signifikan terhadap kinerja pegawai di Bakorwil Bojonegoro?

3. Apakah motivasi berpengaruh signifikan terhadap kinerja pegawai di Bakorwil Bojonegoro?

4. Apakah disiplin kerja berpengaruh signifikan terhadap kinerja pegawai di Bakorwil Bojonegoro?

5. Apakah budaya organisasi berpengaruh signifikan terhadap kinerja pegawai di Bakorwil Bojonegoro? 


\section{Tujuan Penelitian}

Berdasarkan rumusan masalah tersebut dapat dijelaskan tujuan dari penelitian ini adalah sebagai berikut:

1. Untuk mendeskripsikan motivasi, disiplin kerja, budaya organisasi dan kinerja pegawai di Bakorwil Bojonegoro.

2. Untuk menguji dan menganalisis motivasi, disiplin kerja, budaya organisasi secara simultan berpengaruh signifikan terhadap kinerja pegawai di Bakorwil Bojonegoro.

3. Untuk menguji dan menganalisis pengaruh motivasi terhadap kinerja pegawai di Bakorwil Bojonegoro.

4. Untuk menguji dan menganalisis pengaruh disiplin kerja terhadap kinerja pegawai di Bakorwil Bojonegoro.

5. Untuk menguji dan menganalisis pengaruh budaya organisasi terhadap kinerja pegawai di Bakorwil Bojonegoro.

\section{Manfaat Penelitian}

Manfaat penelitian ini terbagi dua, yaitu manfaat secara teoritis dan manfaat secara praktis.

1. Manfaat Teoritis

a. Menambah wawasan untuk penulis mengenai motivasi, disiplin kerja, budaya organisasi dan kinerja pegawai di Bakorwil Bojonegoro.

b. Menjadi referensi atau masukan bagi perkembangan ilmu manajemen sumberdaya manusia khususnya untuk mengetahui pengaruh motivasi, disiplin kerja, budaya organisasi terhadap kinerja pegawai di Bakorwil Bojonegoro.

2. Manfaat Praktis

a. Bagi pimpinan penelitian ini dapat dipakai sebagai sarana untuk menerapkan teori yang telah diperoleh ke dalam praktik yang sesungguhnya di Bakorwil Bojonegoro.

b. Bagi Bakorwil Bojonegoro, penelitian ini dapat digunakan sebagai pertimbangan dalam pengambilan kebijakan terkait dengan kedisiplinan, pemberian motivasi terhadap pegawai dan menerapkan budaya organisasi yang baik sehingga dapat meningkatkan kinerja pegawai.

c. Bagi peneliti, penelitian ini menambah pengetahuan mengenai pengalaman dalam menganalisis pengaruh mengenai motivasi, disiplin kerja, budaya organisasi terhadap kinerja pegawai di Bakorwil Bojonegoro.

d. Bagi pegawai Bakorwil Bojonegoro, penelitian ini dapat memberikan pandangan mengenai pengaruh motivasi, disiplin kerja dan budaya organisasi dalam meningkatkan kinerja pegawai di Bakorwil Bojonegoro.

e. Bagi perguruan tinggi, penelitian ini memberikan kontribusi sebagai bahan untuk menambah referensi perpustakaan kampus sehingga dapat digunakan sebagai bahan penelitian yang dilakukan peneliti berikutnya.

\section{KAJIAN PUSTAKA \\ Kinerja Pegawai}

Menurut Dessler (2015:56) kinerja pegawai adalah prestasi aktual pegawai dibandingkan dengan prestasi yang diharapkan dari pegawai. Kemudian menurut 
Robbins dan Timothy (2015:89) kinerja dapat menjadi hasil dari seorang individu atau dapat berupa hasil dari kerja kelompok daam satu organisasi. Kinerja sebagai hasil kerja yang dicapai oleh individu disesuaikan dengan peran atau tugas individu tersebut dalam suatu instansi pada suatu periode waktu tertentu, yang dihubungkan dengan suatu ukuran nilai atau standar tertentu dari perusahaan dimana individu tersebut bekerja.

Suatu organisasi, baik itu pemerintah maupun swasta, selalu digerakkan oleh sekelompok orang yang berperan aktif untuk mencapai tujuan yang ingin dicapai dari organisasi tersebut. Tujuan organisasi tentunya tidak akan tercapai jika kinerja anggota atau pegawainya tidak maksimal. Menurut Mangkunegara dalam Pasolong (2010:176) kinerja merupakan hasil kerja secara kualitas dan kuantitas yang dicapai oleh seseorang dalam melaksanakan fungsinya sesuai dengan tanggungjawab yang diberikan kepadanya.

Tidak jauh berbeda, Siagian (2010:227) mendefinisikan kinerja sebagai suatu keseluruhan kemampuan seseorang untuk bekerja sedemikian rupa sehingga mencapai tujuan kerja secara optimal dan berbagai sasaran yang telah diciptakan dengan pengorbanan yang secara rasio lebih kecil dibandingkan dengan hasil yang dicapai. Prawirosentono dalam Pasolong (2010:176) lebih cenderung menggunakan kata performance dalam menyebut kata kinerja. Menurutnya performance atau kinerja adalah hasil yang dapat dicapai oleh seseorang atau sekelompok orang dalam suatu organisasi, sesuai dengan tanggungjawab masing-masing dalam rangka mencapai tujuan organisasi bersangkutan secara legal, tidak melanggar hukum dan sesuai dengan moral maupun etika.

Berbagai pendapat diatas dapat menggambarkan bahwa kinerja pegawai dan kinerja organisasi memiliki keterkaitan yang sangat erat, tercapainya tujuan organisasi tidak bisa dilepaskan dari sumber daya yang dimiliki oleh organisasi yang digerakan atau dijalankan pegawai yang berperan aktif sebagai pelaku dalam upaya mencapai tujuan organisasi. Jadi dapat disimpulkan bahwa kinerja pegawai adalah penilaian hasil kerja seseorang dalam suatu organisasi sesuai dengan tugas dan tanggungjawabnya dalam rangka mencapai tujuan organisasi.

\section{Motivasi}

Motivasi adalah suatu emosional yang ada pada diri seseorang, yang dapat dikembangkan sendiri atau juga dapat dikembangkan dari dorongan orang lain yang dapat mempengaruhi hasil kerja seseorang tersebut. (Ardana, 2012:193).Motivasi dapat terbagi menjadi dua yaitu motivasi yang bersifat positif atau negative. Motivasi positif yang dimaksud adalah bagaimana manajer memotivasi pegawai dengan melakukan pendekatan terhadap pegawai yaitu dimana sesorang ditawari sesuatu yang bernilai, maksudnya pegawai diberi pujian dalam melakukan pekerjaanya atau juga dapat diberi pujian karena pekerjaan yang dilakukan sesuai dengan apa yang diinginkan.

Motivasi negatif yang dimaksud adalah pendekatan yaitu dimana seseorang pekerja yang melakukan pekerjaan bekerja dibawah standar akan mendapatkan ancaman berupa ancaman akan di PHK, ancaman akan diturunkan jabatan dan akan diturunkan pangkat. Rantai-rantai keinginan sasaran perilaku pendekatan seseorang dapat diawali dengan sesuatu kebutuhan atau keinginan manusia. 
Motivasi adalah daya pendorong yang mengakibatkan seseorang anggota organisasi mau dan rela untuk mengerahkan kemampuan dalam bentuk keahlian atau keterampilan, tenaga dan waktunya untuk menyelenggarakan berbagai kegiatan yang menjadi tanggung jawabnya dan menunaikan kewajibannya, dalam rangka pencapaian tujuan dan berbagai sasaran organisasi yang telah ditentukan sebelumnya. (Siagian, 2010: 138).

\section{Disiplin Kerja}

Kedisiplinan merupakan fungsi operasional manajemen sumber daya manusia yang terpenting karena semakin baik disiplin kerja pegawai, semakin baik kinerja yang dapat dicapai. Tanpa disiplin yang baik, sulit bagi organisasi untuk mencapai hasil yang optimal. Kedisiplinan merupakan faktor yang utama yang diperlukan sebagai alat peringatan terhadap pegawai yang tidak mau berubah sifat dan perilakunya. Sehingga seorang pegawai dikatakan memiliki disiplin yang baik jika pegawai tersebut memiliki rasa tanggung jawab terhadap tugas yang diberikan kepadanya.

Menurut Rivai dalam Lastriani (2014:356-357) menjelaskan bahwa disiplin kerja adalah suatu alat yang digunakan para manajer untuk berkomunikasi dengan anggota agar mereka bersedia untuk mengubah suatu perilaku serta sebagai suatu upaya untuk meningkatkan kesadaran dan kesediaan seseorang mentaati suatu peraturan perusahaan dan norma-norma sosial yang berlaku. Hasibuan dalam Lastriani (2014: 356-357) memberikan definisi kedisiplinan yang baik yaitu kedisiplinan adalah kesadaran atau kesediaan seseorang mentaati semua peraturan organisasi atau perusahaan dan norma-norma sosial yang berlaku.

Berikut adalah pengertian-pengertian disiplin kerja menurut para ahli diantaranya yaitu Menurut Hasibuan (2011:444) bahwa: "Disiplin kerja adalah kesadaran dan kerelaan seseorang dalam menaati semua peraturan perusahaan dan norma-norma sosial yang berlaku." Menurut Rivai (2011:825) bahwa: "Disiplin kerja adalah suatu alat yang dipergunakan para manajer untuk berkomunikasi dengan pegawai agar mereka bersedia untuk mengubah suatu perilaku serta sebagai suatu upaya untuk meningkatkan kesadaran dan kesedian seorang dalam memenuhi segala peraturan perusahaan."

\section{Budaya Organisasi}

Robbins dan Timothy (2015:256) mendefinisikan budaya organisasi sebagai sebuah sistem makna (persepsi) bersama yang dianut oleh anggota-anggota organisasi, yang membedakan organisasi tersebut dengan oganisasi lainnya. Luthans (2012:137) mengartikan budaya organisasi sebagai pola pemikiran dasar yang diajarkan kepada personel baru sebagai cara untuk merasakan, berpikir, dan bertindak benar dari hari ke hari. Davis dalam Moeheriono (2012:336) mengartikan budaya organisasi sebagai pola keyakinan dan nilai-nilai (values) organisasi yang dipahami, dijiwai, dan dipraktikkan oleh organisasi sehingga pola tersebut memberikan arti tersendiri dan menjadi dasar aturan berperilaku dalam organisasi. 


\section{METODE PENELITIAN \\ Jenis dan Pendekatan Penelitian}

Jenis penelitian ini explanatory research yaitu penelitian yang menjelaskan pengaruh variabel bebas terhadap variabel terikat dan kuesioner sebagai alat pengumpulan data yang pokok (Silalahi 2012:48). Pendekatan dalam penelitian ini adalah pendekatan kuantitatif, karena penelitian ini disajikan dengan angka-angka. Penelitian kuantitatif merupakan pendekatan penelitian yang banyak dituntut menguakan angka, mulai dari pengumpulan data, penafsiran terhadap data tersebut, serta penampilan hasilnya (Arikunto, 2010:19).

Penelitian ini menggunakan pendekatan penelitian kuantitatif. Menurut Sugiyono, (2012:31) Penelitian kuantitatif merupakan metode penelitian yang berlandaskan pada filsafat positivism, digunakan untuk meneliti pada populasi atau sampel tertentu, pengumpulan data menggunakan instrumen penelitian, analisis data bersifat kuantitatif/statistik dengan tujuan untuk menguji hipotesis yang telah ditetapkan.

\section{Lokasi Penelitian}

Penelitian ini dilaksanakan di Bakorwil Bojonegoro yang beralamatkan di Jalan Pahlawan No.5 Kepatihan, Kepatihan, Kec. Bojonegoro, Kabupaten Bojonegoro, Jawa Timur 62111.

\section{Populasi, Sampel dan Teknik Pengambilan Sampel}

Populasi adalah jumlah total dari seluruh unit atau elemen yang akan diteleti (Silahi dalam Wayan, 2011:321). Populasi dalam penelitian ini adalah pegawai Bakorwil Bojonegoro yang berjumlah 62 orang.

Sampel adalah bagian dari jumlah (penelitian populasi) yang mengumpulkan lembaran data koesioner (Sugiono, 2011:162). Sampel dalam penelitian ini adalah semua pegawai Bakorwil Bojonegoro berjumlah 62, yang selanjutnya disebut responden.

Teknik pengambilan sampel yang digunakan dalam penelitian ini diambil secara total atau menggunakan metode sensus sampling sehingga keseluruhan populasi dijadikan sampel penelitian. Metode sensus sampling digunakan mengingat jumlah populasinya sedikit.

\section{Teknik Pengumpulan Data}

Data yang diperlukan dalam penelitian ini bersumber dari responden dimana data tersebut diperoleh melalui penyebaran daftar pertanyaan (angket) kepada para karyawan.

\section{HASIL PENELITIAN DAN PEMBAHASAN Hasil Penelitian}

Statistik deskriptif digunakan untuk menggambarkan suatu data secara statistik. Statistik deskriptif dalam penelitian ini merujuk pada nilai rata-rata (mean) dari seluruh variabel dalam penelitian ini yaitu kinerja pegawai $(\mathrm{Y})$, Motivasi Kerja $\left(\mathrm{X}_{1}\right)$, Budaya Organisasi $\left(\mathrm{X}_{2}\right)$ dan Disiplin $\left(\mathrm{X}_{3}\right)$ sebagaimana ditunjukkan pada tabel berikut. 
Tabel 1. Descriptive Statistics

\begin{tabular}{|l|l|l|l|l|l|}
\hline & N & Minimum & Maximum & Mean & Std. Deviation \\
\hline Motivasi Kerja & 62 & 3.00 & 5.00 & 3.8427 & .43710 \\
\hline Disiplin & 62 & 2.80 & 4.40 & 3.7226 & .32056 \\
\hline Budaya Organisasi & 62 & 3.00 & 4.71 & 3.7816 & .36840 \\
\hline Kinerja pegawai & 62 & 3.14 & 4.71 & 3.7919 & .28137 \\
\hline Valid N (listwise) & 62 & & & & \\
\hline
\end{tabular}

Sumber : Hasil Penelitian, diolah (2019)

Dari data tersebut dapat diketahui variabel Motivasi Kerja memiliki nilai mean sebesar 3.8427, variabel Disiplin kerja memiliki nilai mean sebesar 3.7226, variabel Budaya organisasi memiliki nilai mean sebesar 3.7816, dan variabel kinerja pegawai memiliki nilai mean sebesar 3.7919. Untuk skala penilaian nilai mean pada masingmasing variabel, dapat dilihat pada tabel berikut:

Tabel 2. Kategori Interval

\begin{tabular}{|l|l|}
\hline $0,00-1,80$ & Tidak baik \\
\hline $1,81-2,60$ & Kurang baik \\
\hline $2,61-3,40$ & Cukup baik \\
\hline $3,41-4,20$ & Baik \\
\hline $4,21-5,00$ & Sangat baik \\
\hline
\end{tabular}

Sumber : Hasil Penelitian, diolah (2019)

Dari tabel tersebut dapat diketahui bahwa variabel Motivasi Kerja dalam kategori baik, variabel Disiplin kerja dalam kategori baik, Budaya organisasi dalam kondisi baik, dan variabel kinerja pegawai juga dalam kategori baik.

Setelah mengetahui hasil penelitian statistik diskriptif, maka selanjutnya untuk menguji hipotesis yang telah diajukan pada penelitian ini digunakan analisis statistik inferensial. Untuk menguji hipotesis yang menyatakan bahwa Motivasi Kerja, Disiplin kerja, Budaya organisasi secara simultan mempunyai pengaruh yang signifikan terhadap kinerja pegawai digunakan analisis dengan uji $\mathrm{F}$ yang dapat dilihat pada tabel berikut :

Tabel 3. Hasil Analisis of Varians (ANOVA)

\begin{tabular}{|l|l|l|l|l|l|}
\hline Model & $\begin{array}{l}\text { Sum of } \\
\text { Square }\end{array}$ & df & $\begin{array}{l}\text { Mean } \\
\text { Square }\end{array}$ & F & Sig \\
\hline Regression & 1.753 & 3 & .584 & 11.013 & $.000^{\mathrm{b}}$ \\
$\quad$ Residual & 3.077 & 58 & .053 & & \\
Total & 4.829 & 61 & & & \\
\hline
\end{tabular}

Sumber : Hasil Penelitian, diolah (2019)

Berdasarkan hasil analisis data diperoleh nilai uji $\mathrm{F}$ hitung sebesar 11.013 dengan tingkat signifikansi sebesar 0.000, karena nilai signifikansi 0.000 (lebih kecil dari 0,05) maka Motivasi Kerja, Disiplin kerja, Budaya organisasi secara simultan berpengaruh signifikan terhadap kinerja pegawai.

Dengan demikian hipotesis yang menyatakan bahwa Ada pengaruh antara Motivasi Kerja, Disiplin Kerja, dan Budaya Organisasi secara simultan terhadap kinerja pegawai Bakorwil Bojonegoro diterima. 
Sementara itu, untuk besarnya konstribusi pengaruh Motivasi Kerja, Disiplin kerja dan Budaya organisasi terhadap kinerja pegawai dapat dilihat pada tabel berikut:

Tabel 4. Model Summary

\begin{tabular}{|l|l|l|l|l|}
\hline Model & $\mathbf{R}$ & $\begin{array}{l}\mathbf{R} \\
\text { Square }\end{array}$ & $\begin{array}{l}\text { Adjusted R } \\
\text { Square }\end{array}$ & $\begin{array}{l}\text { Std Error of } \\
\text { the estimate }\end{array}$ \\
\hline 1 & $.602^{\mathrm{a}}$ & .363 & .330 & .23031 \\
\hline
\end{tabular}

Sumber : Hasil Penelitian, diolah (2019)

Hasil analisis data menunjukkan bahwa koefisien determinasi (R-square) sebesar 0.363 atau sebesar 36.3\% Artinya bahwa sebesar 36.3\% kinerja pegawai dapat dijelaskan oleh Motivasi Kerja, Disiplin kerja dan Budaya organisasi, sedangkan sisanya sebesar $63.7 \%$ dijelaskan oleh variabel lain diluar peneltian ini.

Setelah dilakukan pengujian secara simultan (uji F), berikutnya dilakukan pengujian secara parsial (uji t). Hasil analisis data dengan menggunakan SPSS (Statistical Program for Social Science) diperoleh sebagai berikut :

Tabel 5. Hasil Analisis Regresi Linier Berganda

\begin{tabular}{|c|c|c|c|c|c|c|}
\hline \multirow{2}{*}{\multicolumn{2}{|c|}{ Model }} & \multicolumn{2}{|c|}{$\begin{array}{l}\text { Unstandardized } \\
\text { Coefficients }\end{array}$} & \multirow{2}{*}{$\begin{array}{l}\text { Standardize } \\
\text { d } \\
\text { Coefficients } \\
\text { Beta }\end{array}$} & \multirow[t]{2}{*}{$\mathrm{t}$} & \multirow[t]{2}{*}{ Sig. } \\
\hline & & B & Std. Error & & & \\
\hline \multirow[t]{4}{*}{1} & (Constant) & 2.071 & .493 & & 4.199 & .000 \\
\hline & Motivasi Kerja & .284 & .074 & .442 & 3.819 & .000 \\
\hline & Disiplin kerja & .033 & .092 & .038 & .358 & .722 \\
\hline & $\begin{array}{l}\text { Budaya } \\
\text { organisasi }\end{array}$ & .198 & .088 & .260 & 2.252 & .028 \\
\hline
\end{tabular}

Sumber : Hasil Penelitian, diolah (2019)

Berdasarkan hasil analisis data sebagaimana pada tabel tersebut, dapat dibuat persamaan regresi sebagai berikut

$$
\mathrm{Y}=2.071+0.284\left(\mathrm{X}_{1}\right)+0.033\left(\mathrm{X}_{2}\right)+0.198\left(\mathrm{X}_{3}\right)+0.637
$$

Persamaan diatas menunjukkan bahwa ada pengaruh yang positif dari Motivasi Kerja, Disiplin kerja dan Budaya organisasi terhadap peningkatan kinerja pegawai. Nilai konstanta sebesar 2.071 mengandung makna bahwa apabila tidak ada Motivasi Kerja, Disiplin kerja dan Budaya organisasi serta variabel lain, maka tingkat kinerja pegawai sebesar 2.071 satuan.

Nilai 0.284 menunjukkan bahwa apabila ada kenaikan pada Motivasi Kerja sebesar satu satuan maka akan meningkatkan kinerja pegawai sebesar Nilai 0.284 satuan. Nilai 0.033 menunjukkan bahwa apabila ada peningkatan dalam Disiplin kerja sebesar satu satuan akan meningkatkan kinerja pegawai sebesar Nilai 0.033 satuan dan Nilai 0.198 menunjukkan bahwa apabila ada peningkatan dalam Budaya organisasi sebesar satu satuan akan meningkatkan kinerja pegawai sebesar Nilai 0.198 satuan.

Selanjutnya untuk mengetahui pengaruh Motivasi Kerja, Disiplin kerja dan Budaya organisasi secara parsial terhadap kinerja pegawai dapat juga dilihat dari penjelasan sebagai berikut:

a. Nilai t hitung untuk Motivasi Kerja sebesar 3.819 dengan tingkat signifikansi sebesar 0.000 karena nilai signifikansi 0.000 (lebih kecil dari 0,05), maka Motivasi Kerja mempunyai pengaruh signifikan terhadap kinerja pegawai. Sehingga 
berdasarkan hipotesis bahwa secara parsial motivasi berpengaruh signifikan terhadap kinerja pegawai di Bakorwil Bojonegoro diterima

b. Nilai t hitung untuk Disiplin kerja sebesar 0.358 dengan tingkat signifikansi sebesar 0.722 karena nilai signifikansi 0.722 (lebih besar dari 0,05) maka Disiplin kerja mempunyai pengaruh tidak signifikan terhadap kinerja pegawai. Sehingga berdasarkan hipotesis bahwa secara parsial disiplin kerja berpengaruh signifikan terhadap kinerja pegawai di Bakorwil Bojonegoro ditolak

c. Nilai t hitung untuk Budaya organisasi sebesar 2.252 dengan tingkat signifikansi sebesar 0.028 karena nilai signifikansi 0.028 (lebih kecil dari 0,05) maka Budaya organisasi mempunyai pengaruh signifikan terhadap kinerja pegawai. sehingga berdasarkan hipotesis bahwa secara parsial budaya organisasi berpengaruh signifikan terhadap kinerja pegawai di Bakorwil Bojonegoro diterima

\section{Pembahasan}

Dari hasil pengujian deskriptif statistik didapatkan bahwa variabel Motivasi Kerja memiliki nilai mean sebesar 3.8427, variabel Disiplin kerja memiliki nilai mean sebesar 3.7226, variabel Budaya organisasi memiliki nilai mean sebesar 3.7810, dan variabel kinerja pegawai memiliki nilai mean sebesar 3.7919. Dari data tersebut dapat diketahui bahwa variabel Motivasi Kerja dalam kategori baik, variabel Disiplin kerja dalam kategori baik, Budaya organisasi dalam kondisi baik, dan variabel kinerja pegawai juga dalam kategori baik. Sehingga dapat disimpulkan bahwa kondisi variabel motivasi kerja, disiplin kerja, Budaya organisasi dan kinerja pada Bakorwil Bojonegoro semuanya dalam kategori baik.

Berdasarkan analisis data dapat diketahui bahwa motivasi kerja, disiplin kerja dan Budaya organisasi berpengaruh signifikan terhadap kinerja pegawai Bakorwil Bojonegoro. Hal ini dibuktikan dengan oleh besarnya nilai terhitung yang memililiki signifikansi 0.000 (kurang dari 0,05). Hasil dari penelitian ini mendukung hasil penelitian dari Utami (2017) bahwa budaya organisasi, motivasi dan disiplin kerja berpengaruh positif terhadap kinerja pegawai. Hasil penelitian ini menjelaskan bahwa apabila ada peningkatan motivasi kerja, disiplin kerja dan Budaya organisasi secara serentak bersama-sama, maka secara signifikan akan meningkatkan kinerja pegawai Bakorwil Bojonegoro.

Berdasarkan analisis data dapat diketahui bahwa motivasi kerja, berpengaruh signifikan terhadap kinerja pegawai Bakorwil Bojonegoro. Hal ini dibuktikan dengan besarnya nilai t 3.819 yang memiliki signifikansi sebesar 0.000 karena nilai signifikansi 0.000 (lebih kecil dari 0,05). Hasil penelitian ini mendukung hasil penelitian yang dilakukan oleh Gardjito et all (2014) yang menyatakan bahwa motivasi kerja berpengaruh signifikan terhadap kinerja pegawai PT. Karmand Mitra Andalan Surabaya. Penelitian tidak mendukung hasil penelitian yang dilakukan oleh Hardjono (2013) bahwa Ada pengaruh yang positif tetapi tidak signifikan antara Motivasi terhadap Kinerja Pegawai pada Kantor Kecamatan Mijen. Dengan demikian dapat dijelaskan bahwa apabila ada peningkatan pada motivasi kerja, maka secara signifikan juga kinerja pegawai Bakorwil Bojonegoro akan meningkat.

Berdasarkan analisis data dapat diketahui bahwa disiplin kerja berpengaruh tidak signifikan terhadap kinerja pegawai Bakorwil Bojonegoro. Hal ini dibuktikan 
dengan besarnya nilai t 0.358 yang memiliki signifikansi sebesar 0.722 karena nilai signifikansi 0.722 (lebih besar dari 0,05). Hasil penelitian ini tidak mendukung hasil penelitian yang dilakukan oleh Lastriani (2014) bahwa disiplin memiliki pengaruh yang signifikan dalam meningkatkan kinerja anggota Satlantas Polresta Pekanbaru dengan koefisien determinasi sebesar 0,854 atau 85,4\%. Hasil penelitian ini juga tidak mendukung penelitian Hardjono (2013) yang mengatakan bahwa disiplin kerja secara parsial berpengaruh secara signifikan terhadap kinerja pegawai. Hasil penelitian ini medukung penelitian Mamesah et all (2016) yang menyatakan bahwa disiplin kerja tidak berpengaruh secara signifikan terhadap kinerja pegawai. Dengan demikian dapat dijelaskan bahwa apabila ada peningkatan pada disiplin kerja, maka kinerja pegawai Bakorwil Bojonegoro tidak akan meningkat. Hal ini dapat disebabkan karena disiplin kerja pegawai di Bakorwil Bojonegoro sudah baik yang dilihat dari tingginya perhatian pegawai kepada hal-hal rinci serta pegawai selalu berorientasi baik itu pada hasil, orang maupun dengan tim. Tingkat keagresifan dan stabilitas pegawai dalam menyelesaikan bpekerjaan juga sudah baik. Sehingga apabila ada peningkatan pada disiplin kerja tidak akan mempengaruhi terhadap peningkatan kinerja pegawai Bakorwil Bojonegoro.

Berdasarkan analisis data dapat diketahui bahwa budaya organisasi, berpengaruh signifikan terhadap kinerja pegawai Bakorwil Bojonegoro. Hal ini dibuktikan dengan besarnya nilai t 2.252 yang memiliki signifikansi sebesar 0.028 karena nilai signifikansi 0.028 (lebih kecil dari 0,05). Hasil ini mendukung hasil penelitian yang dilakukan oleh Utami (2017) yang mengatakan bahwa budaya organisasi memiliki pengaruh yang signifikan terhadap kinerja pegawai. Sehingga dapat dikatakan bahwa apabila ada peningkatan pada budaya organisasi maka mempengaruhi peningakatan kinerja pegawai Bakorwil Bojonegoro.

\section{KESIMPULAN DAN SARAN Kesimpulan}

Berdasarkan hasil analis data dan pembahasan yang sudah dilakukan, maka dapat disimpulkan sebagai berikut:

1. Kondisi variabel motivasi kerja, Disiplin kerja, Budaya organisasi dan kinerja pegawai pada Bakorwil Bojonegoro semuanya dalam kategori baik.

2. Motivasi kerja, Disiplin kerja dan Budaya organisasi secara simultan mempunyai pengaruh yang signifikan terhadap kinerja pegawai Bakorwil Bojonegoro. Variabel motivasi kerja, Disiplin kerja dan Budaya organisasi pada penelitian ini memberikan kontribusi sebesar $36.3 \%$ terhadap kinerja pegawai Bakorwil Bojonegoro. Sedangkan sisanya $63.7 \%$ merupakan pengaruh faktor lain diluar penelitian ini.

3. Variabel motivasi kerja secara parsial mempunyai pengaruh yang signifikan terhadap kinerja pegawai Bakorwil Bojonegoro.

4. Variabel disiplin kerja secara parsial mempunyai pengaruh yang tidak signifikan terhadap kinerja pegawai Bakorwil Bojonegoro.

5. Variabel budaya organisasi memiliki pengaruh yang signifikan terhadap kinerja pegawai Bakorwil Bojonegoro 


\section{Saran}

Berdasarkan hasil penelitian dan kesimpulan, penulis dapat mengajukan beberapa saran sebagai berikut :

1. Perlu adanya peningkatan variabel motivasi kerja dan Budaya organisasi karena secara parsial variabel tersebut mempunyai pengaruh yang signifikan terhadap peningkatan kinerja pegawai Bakorwil Bojonegoro.

2. Pada penelitian lebih lanjut perlu mencari variabel lain selain motivasi kerja, variabel Disiplin kerja, Budaya organisasi yang berpengaruh terhadap kinerja pegawai, karena masih ada sebesar $63.8 \%$ yang bisa dijelaskan oleh variabel lain selain dari peneltian ini. Tertutama variabel disiplin kerja, karena variabel tersebut tidak mempunyai pengaruh yang signifikan terhadap peningkatan kinerja pegawai Bakorwil Bojonegoro.

\section{DAFTAR PUSTAKA}

Adnyana, Putra. 2013. Pengaruh Kepemilikan Manajerial Terhadap Hubungan Antara Kinerja Dengan Nilai Perusahaan. E-Journal Universitas Udayana. Vol. 5, No.3, 2013.

Adrianto, Rizky. 2013. Analisis Faktor-Faktor Yang Mempengaruhi Penyerapan Tenaga Kerja Pada Industri Kecil (Studi Kasus Pada Industri Krupuk Rambak di Kelurahan Bangsal, Kecamatan Bangsal, Kabupaten Mojokerto. Jurnal Ilmiah. Fakultas Ekonomi dan Bisnis Universitas Brawijaya. Malang.

Ardana, I Komang dkk. 2012. Manajemen Sumber Daya Manusia. Yogyakarta: Graha ilmu.

Arikunto, Suharsimi. 2010. Prosedur Penelitian Suatu Pendekatan Praktik. Jakarta: Rineka Cipta.

Azra, Azyumardi. 2010. Identitas dan Krisis Budaya Membangun Multikulturalisme Indonesia. Terarsip dalam http://www.lpmpbanten.net/berita-item/identitasdankrisis-budaya-membangun-multikulturalisme-indonesia.html. Diakses pada tanggal 8 Agustus 2012.

Dessler, Gary. 2015. Manajemen Sumber Daya Manusia. Jakarta: Salemba. Empat.

Fadel, Muhammad. 2009. Reinventing Government (Pengalaman Dari Daerah). PT. Elex Media Komputindo. Jakarta.

Fred Luthans, 2010, Perilaku Organisasi. Edisi Sepuluh, PT. Andi: Yogyakarta.

Gardjito, Herlambang, et al. 2014. Pengaruh Motivasi Kerja dan Lingkungan Kerja terhadap Kinerja Karyawan Produksi PT. Karmand Mitra Andalan Surabaya. Jurnal Universitas Brawijaya.

Hardjono, tri. 2013. Analisis Pengaruh Motivasi, Disiplin Kerja dan Kemampuan Kerja terhadap Kinerja Pegawai Negri Sipil. Jurnal Skripsi : Psi Udinus

Hasibuan, Malayu S.P, 2011, Manajemen Dasar, Pengertian, dan Masalah. Edisi Revisi. Jakarta: Bumi Aksara.

Lastriani, Elvi. 2014. Pengaruh Disiplin terhadap Kinerja Anggota pada Satlantas Polresta Pekanbaru. Jurnal Ilmiah Ekonomi dan Bisnis Vol. 11 No. 2 September 2014

Luthans, Fred. 2012. Perilaku Organisasi. Yogyakarta: Penerbit Andi.

Mahmudi, 2010. Manajemen Kinerja Sektor Publik. Yogyakarta : UPP AMP YKPN. 
Mangkunegara, A.A.Anwar Prabu. 2011. Manajemen Sumber Daya Manusia Perusahaan. Bandung: PT.Remaja Rosda Karya

Moeheriono. 2012. "Pengukuran Kinerja Berbasis Kompetensi". Jakarta: Raja Grafindo Persada.

Pabundu Tika. 2014. Budaya Organisasi dan Peningkatan Kinerja Karyawan. Jakarta : Bumi Aksara.

Pasolong, Harbani. 2010. Teori Administrasi Publik. Bandung: Alfabeta.

Pramadewi, Arwinence. 2015. Influence of Organizational Climate, Professional Competence of the Work Motivation and Impact on the PerformanceFaculty of Economics, University of Riau. European Journal of Business and Management Vol.7, No.14, 2015.

Putra, Riyan, S. 2013. Pengaruh Budaya Perusahaan Terhadap Prestasi Kerja Karyawan Pt Pembangkitan Jawa- Bali Surabaya Unit Pelayanan Pemeliharaan. Jmk, Vol. 1 5, No. 2, September 2013

Rivai, Veithzal. 2011, Manajemen Sumber Daya Manusia untuk Perusahaan: dari Teori ke Praktik, Jakarta : RajaGrafindo Persada

Rizky, Akbar, Dimas. 2014. Pengaruh Kemampuan, Motivasi dan Kepuasan Kerja Terhadap Kinerja Pegawai Negeri Sipil di Lingkungan Kecamatan Tambaksari Surabaya. Jurnal Kebijakan dan Manajemen Publik Volume 2, Nomor 1. h. 1-10.

Robbins, S.P dan Timothy A. Judge. 2015. Perilaku Organisasi, Edisi 16. Jakarta: Salemba Empat.

Siagian,S.P. 2010. Teori Motivasi dan Aplikasinya. Jakarta: PT. Rineka Cipta

Silalahi, Ulber. 2012. Metode Penelitian Sosial. Bandung: PT. Refika Aditama

Sinambela, Lijan Poltak. 2012. Kinerja Pegawai. Yogyakarta: Graha Ilmu.

Singodimedjo, 2010. Menejemen Sumber Daya Manusia. Jakarta : Bumi Aksara

Sugiyono, 2012, Metode Penelitian Kuantitatif, Kualitatif dan R\&D, Bandung: Alfabeta.

Sutrisno, Edy. 2011. Manajemen Sumber Daya Manusia. Penerbit: Jakarta, Kencana.

Undang- Undang No. 32 Tahun 2004 tentang Pemerintah Daerah

Undang-Undang Nomor 43 Tahun 1999 tentang penilaian pelaksanaan pekerjaan PNS

Utami, Agustina Setyo. 2017. Pengaruh Budaya Organisasi, Motivasi dan Disiplin Kerja terhadap Kinerja Karyawan pada KSP Lohjinawe. Jurnal Ilmu Administrasi Bisnis S1 Undip

Wardana. 2008. Analisis Pengaruh Motivasi Kerja, Disiplin Kerja, Pendidikan dan Pelatihan Terhadap Kinerja Guru Sekolah Dasar di Kecamatan Gayungan Kota Surabaya. Jurnal Ekonomi dan Bisnis. Vol II. No.1. 